DOI: 10.21315/aos2021.16.1.2

ARTICLE INFO

Submitted: $27 / 7 / 2020$

Accepted: 10/1/2021

Online: 25/6/2021

\section{The Optimum Duration of Flushing Dental Unit Waterlines for Microbial Removal}

\author{
John Chong Keat Hon a*, Siti Noor Adnalizawati Adnan, \\ Nur Aqilah Ismailc
}

\begin{abstract}
${ }^{a}$ Department of Oral and Maxillofacial Surgery, Faculty of Dentistry, Universiti Sains Islam Malaysia, 55100 Kuala Lumpur, Malaysia

${ }^{6}$ Department of Oral Biology and Basic Sciences, Faculty of Dentistry, Universiti Sains Islam Malaysia, 55100 Kuala Lumpur, Malaysia

'Klinik Pergigian Kuala Ketil, 09310 Kuala Ketil, Baling, Kedah, Malaysia
\end{abstract}

${ }^{\star}$ Corresponding author: drjohn@usim.edu.my

How to cite this article: John Chong KH, Adnan SNA, Ismail NA (2021). The optimum duration of flushing dental unit waterlines for microbial removal. Arch Orofac Sci, 16(1): 13-23. https://doi.org/10.21315/aos2021.16.1.2

To link to this article: $h$ ttps://doi.org/10.21315/aos2021.16.1.2

\title{
ABSTRACT
}

This study aims to evaluate the optimum duration of flushing dental unit waterlines (DUWLs) in Universiti Sains Islam Malaysia (USIM) dental polyclinics for removal of heterotrophic bacteria. Water samples were obtained from triple air syringes at each dental chair from oral surgery clinic, outpatient clinic and polyclinic 17 at Faculty of Dentistry, USIM after 16 and 64 hours of not operating the dental units as baseline samples. This is followed by sampling after continuous flushing at 30 seconds, 1 minute, 2 minutes and 3 minutes of flushing duration. The levels of heterotrophic plate count (HPC) for each flushing duration were determined by quantification of colony forming units (CFUs) after cultivation of samples on plate count agar (PCA), R2A agar and 5\% sheep blood agar (SBA). Statistically, there was no significant reduction in CFUs of HPC for all flushing duration compared to baseline $(P>0.05)$ with the most notable HPC reducing level after 1 minute and 3 minutes of flushing DUWLs. However, HPC level at USIM dental clinics is still exceeding the recommendation by Centers for Disease Control and Prevention (CDC) which should be less than $500 \mathrm{CFU} / \mathrm{mL}$. The existing method of controlling DUWLs contamination in USIM dental clinics is only by flushing DUWLs 1 minute every morning prior to dental treatment as recommended by Malaysian Dental Council (MDC) without the use of chemical germicides. Thus, the flushing method alone is not reliable to reduce the number of microorganisms in the DUWLs.

Keywords: Biofilms, dental unit waterlines, flushing duration, heterotrophic plate count

\section{INTRODUCTION}

Water from dental unit waterlines (DUWLs) is essential to cool dental instruments, irrigate the oral cavity and service a wide range of dental procedures. Biofilms are microbial populations which adhere to surfaces and are mostly located at the liquid- surface interface. They predominantly consist of bacteria and other microorganisms in a matrix of polymers derived from the environment and the microorganism itself. Biofilm microorganisms have a greater chance to survive compared to microorganisms in water and planktons because biofilm microorganisms are able to 
self-form a complex matrix that can protect them from external injury, despite the biofilms also exhibit low metabolic activity and they are more resistant to antibiotics. Therefore, control of biofilms as a general approach should be considered (Pouralibaba et al., 2011; Hernández-Jiménez et al., 2013).

Panagakos et al. (2001) suggested that the main source of contamination in DUWL is from community water supply. Bacteria and human pathogens such as Pseudomonas spp. (Mavridou et al., 2006; Al-Hiyasat et al., 2007; Ma et al., 2012), Legionella pneumophila (Walker et al., 2000; Mavridou et al., 2006) and Mycobacterium spp. (Walker et al., 2000; Mavridou et al., 2006) have been isolated from DUWLs. A rare type of bacteria species such as Staphylococcus spp. also was found (Singh et al., 2003). The issue of water quality from DUWLs has been a major concern for many years since it might pose risk of occupational hazards to the dental health care professionals as well as risks to the patients. (Pankhurst, 2003; Szymanska \& Dutkiewicz, 2008).

The high level of microbial contamination in DUWLs violates basic infection control practice. American Dental Association (ADA) (1999) recommends that water used in dental treatment should contain a bacterial level of less than $200 \mathrm{CFU} / \mathrm{mL}$ (Mills, 2000) whereas Centers for Disease Control and Prevention (CDC) recommends water used in dental treatment should contain aerobic heterotrophic plate count (HPC) of less than $500 \mathrm{CFU} / \mathrm{mL}$ (Kohn et al., 2003).

CDC (2003) recommends that any devices (e.g. handpieces, ultrasonic scalers, or air/ water syringes) that enter a patient's mouth should be flushed for at least 20 seconds to 30 seconds between patients (Kohn et al., 2003). Clinical Practice Guideline on infection control by Malaysian Dental Council (MDC) (2007) stated that flushing should be done for 1 minute every morning prior to dental treatment and with handpieces attached for 20 seconds to 30 seconds between each patient.
Rice et al. (2006) summarised that flushing can significantly decrease the HPC microscopic organisms present in water utilized for dental treatment. However, another finding in this study showed that the flushing procedure did not effectively reduce the occurrence of either Legionella spp. or protozoa. In concord with the most recent CDC proposals, this study confirmed that flushing alone is not a promising approach but a dependable strategy for improving water quality utilized in dental treatment (Kohn et al., 2003).

The importance of awareness on possible contamination in DUWLs has been highlighted since microbial contamination violated the principle of infection control in dental health-care settings. Since then, there have been several alternatives to increase the standard of water protection recommended by ADA including DUWLs flushing. However, to date, there is still a lack of data on the effectiveness of DUWLs flushing. The aim of this study was therefore to evaluate and compare the optimum duration of flushing DUWLs for the removal of heterotrophic bacteria in dental units that are not operating for 16 and 64 hours respectively in USIM dental polyclinics.

\section{MATERIALS AND METHODS}

\section{The Selection of Sample}

This cross-sectional study was carried out in three dental settings at level 17 of the Faculty of Dentistry, USIM namely oral surgery specialist (OS) clinic, outpatient (OP) clinic and polyclinic 17. Each dental setting is well-equipped with only one dental chair unit except for polyclinic 17 with a total of 35 dental chair units. Besides both units in OP and OS clinic, one dental chair unit was randomly selected to represent polyclinic 17. Water samples from each dental chair unit were collected after 16 and 64 hours of non-operating same dental units. The water samples were collected using sterile technique with clean sterile gloves, 
cleaning the outside surfaces of the triple air syringe with sterile disinfectant cotton containing $70 \%$ ethanol and collection of waterline samples into sterile bottles. The first $50 \mathrm{~mL}$ sample was taken from each triple air syringes without flushing as baseline data, followed by collection of $50 \mathrm{~mL}$ of water samples after flushing for the duration of 30 seconds, 1 minute, 2 minutes and 3 minutes using the same triple air syringes continuously on the same day. The samples were then placed in the refrigerator at $3^{\circ} \mathrm{C}$ no more than 24 hours.

\section{Bacteria Cultivation}

Each water sample was serially diluted on the same day at $1: 10^{1}$ to $1: 10^{3}$ prior to cultivation on R2A agar (Oxoid, UK) using spread plate technique with a heated hockey stick. The remaining water samples were then centrifuged for 10 minutes at $4^{\circ} \mathrm{C}$ and at a speed of $10,000 \mathrm{rpm}$. The sediment was then cultured on plate count agar (PCA) (Oxoid, UK) and 5\% sheep blood agar (SBA) (Oxoid, UK) using the same technique except for water samples from polyclinic 17 that use pour plate technique. SBA was incubated at $35^{\circ} \mathrm{C}$ for 48 hours (Payment et al., 1994). While PCA was incubated at $35^{\circ} \mathrm{C}$ for 48 hours and $\mathrm{R} 2 \mathrm{~A}$ agar at $25^{\circ} \mathrm{C}$ for seven days (Dichter et al., 2017). Control plates were incorporated as sterility control for all three types of agar used. The colony-forming units (CFUs) in serially diluted water samples were counted for each incubated plate with the aid of a colony counter. CFUs more than $300 \mathrm{CFU} / \mathrm{mL}$ were considered as Too Numerous to Count (TNTC) (Peter et al., 2008). The actual CFUs counts of bacteria for each plate were determined by direct multiplication of each CFUs count to their respective dilution factors $\left(1: 10^{1}\right.$ to $\left.1: 10^{3}\right)$.

\section{Data Analysis}

All CFUs data were log transformed prior to analysis. Data was analysed using Microsoft Excel 2013 to determine the reducing level of HPC of different flushing duration. Kruskal-
Wallis test was used after descriptive analysis using SPSS version 21 to compare the effectiveness of each flushing duration to the baseline. Wilcoxon-signed rank test was used to compare the effective flushing time for 16 and 64 hours of not operating dental units.

\section{RESULT}

Table 1 shows the total mean of HPC bacteria for OP clinic, OS clinic and polyclinic 17 after 16 and 64 hours of not operating dental chairs at 0-hour, 30 seconds, 1 minute, 2 minutes and 3 minutes of flushing. After 16 hours of not operating the dental chair at OP clinic (Fig. 1), the mean of HPC that formed in SBA was $0.5 \log _{10} \mathrm{CFU} / \mathrm{mL}$, PCA was $3.2 \log _{10} \mathrm{CFU} / \mathrm{mL}$ and $\mathrm{R} 2 \mathrm{~A}$ agar was $3.1 \log _{10} \mathrm{CFU} / \mathrm{mL}$ at 0 -hour respectively with the total mean of HPC was $6.8 \log _{10}$ $\mathrm{CFU} / \mathrm{mL}$. After 1 minute of continuous flushing, HPC was only formed in R2A agar with the mean of HPC was $0.5 \log _{10}$ $\mathrm{CFU} / \mathrm{mL}$. However, the total mean of HPC was then increased to $0.8 \log _{10}$ $\mathrm{CFU} / \mathrm{mL}$ in R2A agar only after 2 minutes of continuously flushing meanwhile both PCA and R2A agar recorded $1.4 \log _{10}$ $\mathrm{CFU} / \mathrm{mL}$ and $0.6 \log _{10} \mathrm{CFU} / \mathrm{mL}$ respectively after 3 minutes of flushing. The highest HPC level reduction was $6.3 \log _{10} \mathrm{CFU} / \mathrm{mL}$ which was noted after 1 minute of flushing.

In comparison to after 64 hours of not operating dental chair at OP clinic (Fig. 1), the mean level of HPC in all three agars escalated to $12.4 \log _{10} \mathrm{CFU} / \mathrm{mL}$ at 0 -hour with R2A agar recorded the highest mean of HPC, $5.8 \log _{10} \mathrm{CFU} / \mathrm{mL}$. The total mean of HPC did reduce in all three agars after 30 seconds and 1 minute of continuously flushing. However, the colonies bounced back to $6.7 \log _{10} \mathrm{CFU} / \mathrm{mL}$ and $6.5 \log _{10}$ $\mathrm{CFU} / \mathrm{mL}$ respectively in $\mathrm{R} 2 \mathrm{~A}$ agar after 2 minutes and 3 minutes of continuous flushing. No colony has been recorded in both SBA and PCA since after the initial 30 seconds of continuous flushing. In contrast to previous results for 16 hours of 
not operating a dental chair at OP clinic, the highest reduction of HPC level was recorded after 30 seconds of flushing where it reduced by $8.7 \log _{10} \mathrm{CFU} / \mathrm{mL}$.

In OS clinic, the total mean of HPC after 16 hours of not operating the dental chair (Fig. 2) was initially $7.3 \log _{10} \mathrm{CFU} / \mathrm{mL}$ with $0.5 \log _{10} \mathrm{CFU} / \mathrm{mL}$ in SBA, $1.4 \log _{10}$ $\mathrm{CFU} / \mathrm{mL}$ in PCA and $5.4 \log _{10} \mathrm{CFU} / \mathrm{mL}$ in R2A agar, respectively. The total mean of HPC showed reduction in all three agars as soon as continuous flushing from 0-hour till after 1 minute of flushing. However, the total mean of HPC climbed up to $3.4 \log _{10}$ $\mathrm{CFU} / \mathrm{mL}$ after 2 minutes of flushing and it was only recorded in $\mathrm{R} 2 \mathrm{~A}$ agar. The total mean of HPC was then continuously raised by both PCA (1.7 $\left.\log _{10} \mathrm{CFU} / \mathrm{mL}\right)$ and R2A (2.2 $\left.\log _{10} \mathrm{CFU} / \mathrm{mL}\right)$ after continuous flushing for 3 minutes. The most notable HPC level reduction was after 1 minute of flushing with a reduction of $5.2 \log _{10}$ $\mathrm{CFU} / \mathrm{mL}$.
There was a slight increase in the mean level of HPC after 64 hours of not operating a dental chair in OS clinic (Fig. 2) recorded in all three agars $\left(7.8 \log _{10} \mathrm{CFU} / \mathrm{mL}\right)$ at 0 -hour. The highest level of HPC reduction was only recorded after 3 minutes of flushing and it was recorded in both SBA $\left(0.5 \log _{10}\right.$ $\mathrm{CFU} / \mathrm{mL})$ and R2A agar $\left(2.1 \log _{10} \mathrm{CFU} / \mathrm{mL}\right)$ with the total mean of HPC was $2.6 \log _{10}$ $\mathrm{CFU} / \mathrm{mL}$.

The result for polyclinic 17 (Table 1) shows a peculiarity in comparison with OS clinic and OP clinic. The fluctuating pattern of mean HPC level for both after 16 hours and 64 hours of not operating dental chair at polyclinic 17 were the same. At 0-hour, the mean HPC level was reported as TNTC in all three agars after 16 and 64 hours of not operating a dental chair at polyclinic 17 . It was then reduced drastically after 30 seconds of flushing then bizarrely climbed up after 1 minute and 2 minutes of flushing before it went down again after 3 minutes flushing.

TOTAL MEAN HETEROTROPHIC PLATE COUNT

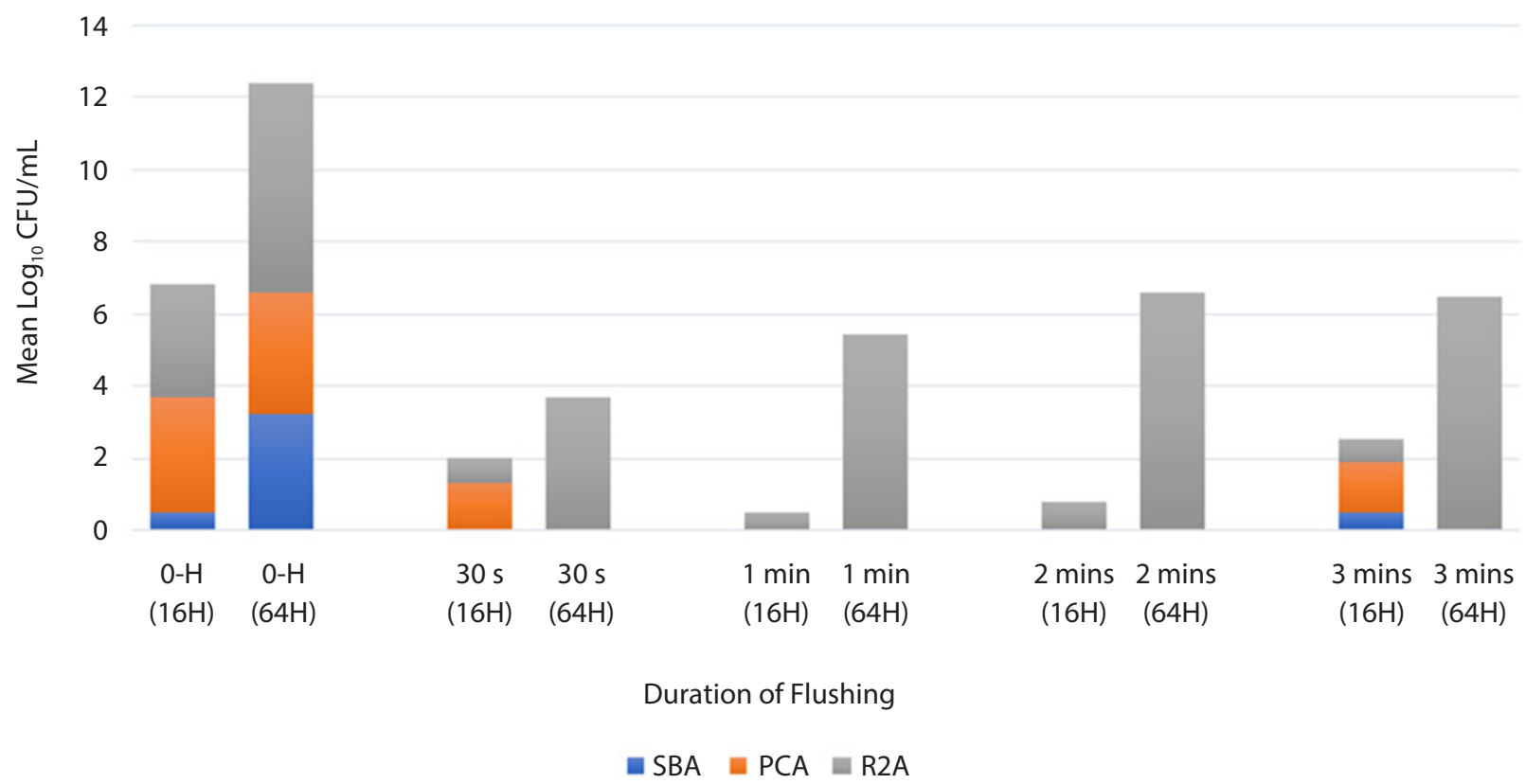

Fig. 1 Total mean of heterotrophic plate count bacteria $\left(\log _{10} \mathrm{CFU} / \mathrm{mL}\right)$ at initial and after flushing of four duration times as determined by plating on R2A agar, PCA and SBA for OP clinic after 16 and 64 hours of not operating dental chairs. 
TOTAL MEAN HETEROTROPHIC PLATE COUNT

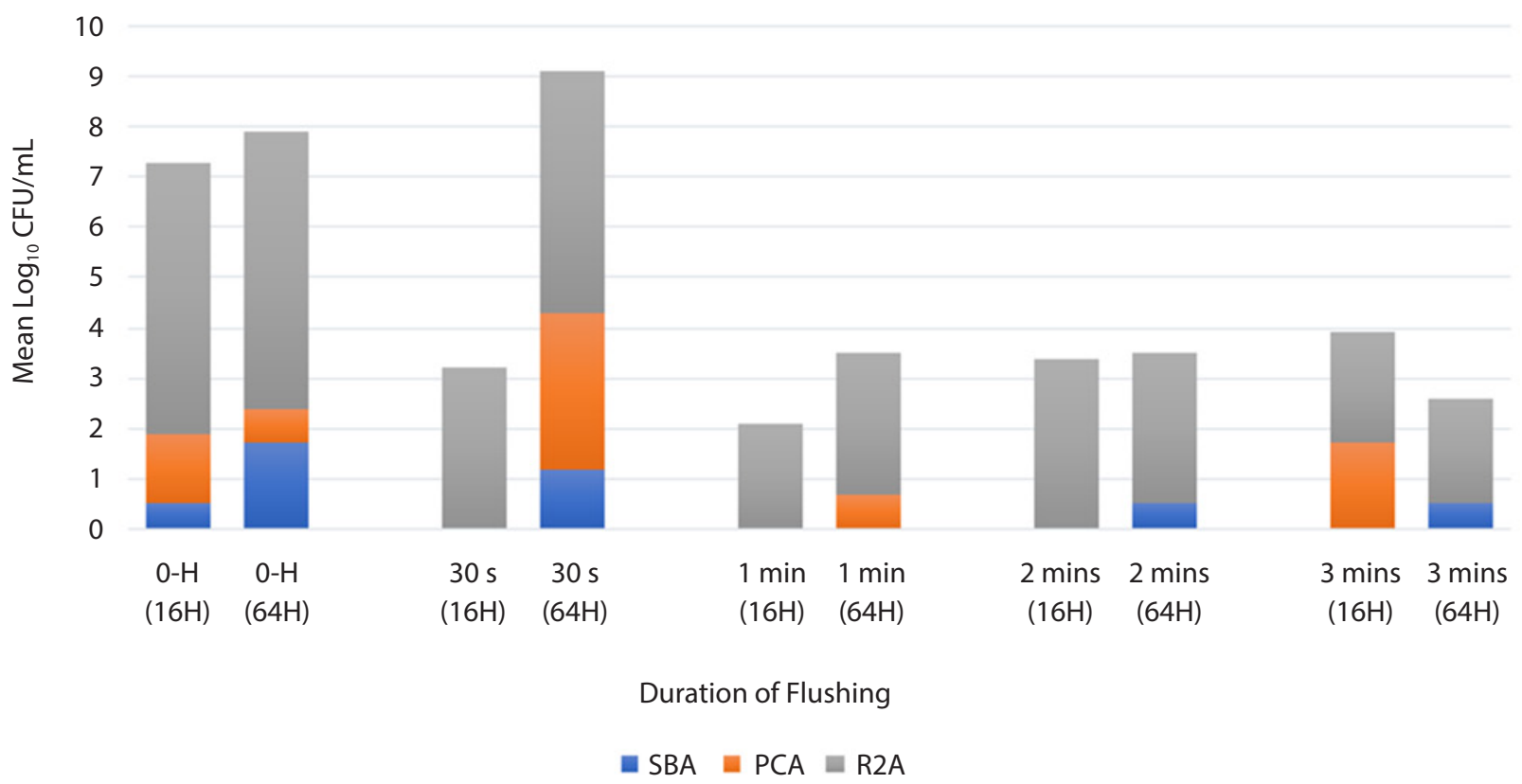

Fig. 2 Total mean of heterotrophic plate count bacteria $\left(\log _{10} \mathrm{CFU} / \mathrm{mL}\right)$ at initial and after flushing of four duration times as determined by plating on R2A agar, PCA and SBA for OS clinic after 16 and 64 hours of not operating dental chairs.

Table 1 Total mean of heterotrophic plate count bacteria $\left(\log _{10} \mathrm{CFU} / \mathrm{mL}\right)$ at initial and after flushing of four different duration times as determined by plating on R2A agar, PCA and SBA for OP clinic, OS clinic and polyclinic 17 after 16 and 64 hours of not operating dental chairs

\begin{tabular}{|c|c|c|c|c|c|}
\hline \multirow{2}{*}{ Research venue (Time) } & \multicolumn{5}{|c|}{$\begin{array}{l}\text { Heterotrophic plate count bacteria }\left(\log _{10} \mathrm{CFU} / \mathrm{mL}\right) \text { according to duration of flushing } \\
\qquad(\text { Mean } \pm \text { SD) }\end{array}$} \\
\hline & Baseline (0-H) & $30 \mathrm{sec}$ & 1 minute & 2 minutes & 3 minutes \\
\hline OP clinic (16H) & $6.8 \pm 1.5$ & $1.9 \pm 0.6$ & $0.5 \pm 0.3$ & $0.8 \pm 0.4$ & $2.5 \pm 0.5$ \\
\hline OP clinic (64H) & $12.4 \pm 1.4$ & $3.7 \pm 2.1$ & $5.4 \pm 3.1$ & $6.7 \pm 3.8$ & $6.5 \pm 3.8$ \\
\hline OS clinic (16H) & $7.3 \pm 2.6$ & $3.2 \pm 1.8$ & $2.1 \pm 1.2$ & $3.4 \pm 1.9$ & $3.9 \pm 1.2$ \\
\hline OS clinic (64H) & $7.8 \pm 2.5$ & $9.1 \pm 1.8$ & $3.5 \pm 1.5$ & $3.5 \pm 1.6$ & $2.6 \pm 1.1$ \\
\hline Polyclinic $17(16 \mathrm{H})$ & *TNTC & $5.4 \pm 1.0$ & $7.3 \pm 0.8$ & *TNTC & $6.0 \pm 1.2$ \\
\hline Polyclinic $17(64 \mathrm{H})$ & *TNTC & $7.5 \pm 0.5$ & $7.2 \pm 0.7$ & $11.0 \pm 1.7$ & $7.2 \pm 0.6$ \\
\hline
\end{tabular}

Note: *TNTC - Too numerous to count

In Table 2, Kruskal-Wallis test shows that there is no significant difference between flushing duration of 30 seconds, 1 minute, 2 minutes and 3 minutes of flushing with baseline data for the removal of heterotrophic bacteria in DUWLs $(P>0.05)$. Wilcoxon signed rank test had proven significant difference of flushing DUWLs between 16 and 64 hours of not operating dental chairs at OP $(P<0.05)$ but result was not significant at $\mathrm{OS}$ clinic $(P>0.05)$ (Table 3$)$. Statistical analysis for polyclinic 17 was not processed due to mean HPC level reported as TNTC. 
Table 2 Kruskal-Wallis Test showed that there is no significant difference between flushing duration of 30 seconds, 1 minute, 2 minutes and 3 minutes of flushing with baseline data for the removal of heterotrophic bacteria in DUWLs $(p>0.05)$

\begin{tabular}{|c|c|c|c|c|c|c|}
\hline \multirow{2}{*}{$\begin{array}{l}\text { Research venue } \\
\text { (Time) }\end{array}$} & \multicolumn{6}{|c|}{ Test statistics } \\
\hline & Flushing duration & $N$ & Mean rank & df & $\chi^{2}$ & $p$ \\
\hline \multirow[t]{5}{*}{$16 \mathrm{H}$ OS clinic } & 0-Hour & 3 & 10.67 & & & \\
\hline & $30 \mathrm{sec}$ & 3 & 7.00 & & & \\
\hline & $1 \mathrm{~min}$ & 3 & 6.33 & 4 & 1.963 & 0.743 \\
\hline & 2 mins & 3 & 7.33 & & & \\
\hline & 3 mins & 3 & 8.67 & & & \\
\hline \multirow[t]{5}{*}{ 16H OP clinic } & 0-Hour & 3 & 12.00 & & & \\
\hline & $30 \mathrm{sec}$ & 3 & 8.33 & & & \\
\hline & $1 \mathrm{~min}$ & 3 & 4.33 & 4 & 5.920 & 0.205 \\
\hline & 2 mins & 3 & 5.67 & & & \\
\hline & 3 mins & 3 & 9.67 & & & \\
\hline \multirow[t]{5}{*}{$64 \mathrm{H}$ OS clinic } & 0-Hour & 3 & 10.17 & & & \\
\hline & $30 \mathrm{sec}$ & 3 & 11.67 & & & \\
\hline & $1 \mathrm{~min}$ & 3 & 6.50 & 4 & 4.549 & 0.337 \\
\hline & 2 mins & 3 & 6.17 & & & \\
\hline & 3 mins & 3 & 5.50 & & & \\
\hline \multirow[t]{5}{*}{$64 \mathrm{H} \mathrm{OP}$ clinic } & 0-Hour & 3 & 10.67 & & & \\
\hline & $30 \mathrm{sec}$ & 3 & 6.67 & & & \\
\hline & $1 \mathrm{~min}$ & 3 & 7.00 & 4 & 1.765 & 0.779 \\
\hline & 2 mins & 3 & 8.00 & & & \\
\hline & 3 mins & 3 & 7.67 & & & \\
\hline
\end{tabular}

Note: ${ }^{*} p<0.05$ indicates statistically significant

Table 3 Wilcoxon Signed Ranks Test showed significant difference of flushing DUWLs between 16 and 64 hours of not operating dental chairs at OP clinic

\begin{tabular}{|c|c|c|c|c|c|c|c|c|c|}
\hline & \multicolumn{3}{|c|}{ Negative rank } & \multicolumn{3}{|c|}{ Positive rank } & \multicolumn{3}{|c|}{ Test statistics } \\
\hline & $n$ & $\begin{array}{c}\text { Mean } \\
\text { rank }\end{array}$ & $\begin{array}{l}\text { Sum of } \\
\text { ranks }\end{array}$ & $n$ & $\begin{array}{c}\text { Mean } \\
\text { rank }\end{array}$ & $\begin{array}{l}\text { Sum of } \\
\text { ranks }\end{array}$ & Ties & $\mathbf{z}$ & $P$ \\
\hline $64 \mathrm{H} \mathrm{OP}-16 \mathrm{H} \mathrm{OP}$ & $0^{\mathrm{a}}$ & 0.00 & 0.00 & $5^{b}$ & 3.00 & 15.00 & 0 & $-2.023^{b}$ & $0.043^{*}$ \\
\hline
\end{tabular}

Note: ${ }^{*} P<0.05$ indicates statistically significant; ${ }^{a}$ Wilcoxon Signed Ranks Test; ${ }^{\mathrm{b}}$ Based on negative ranks

\section{DISCUSSION}

This study evaluated the optimum duration required to flush DUWLs in USIM dental polyclinics in order to remove HPC which would pose risk for healthcare-associated infection to the patients and attending clinicians. The efficiency of flushing was measured by determining the reduction of total mean HPC level after flushing
DUWLs and this was applied and compared for both 16 and 64 hours of not operating the dental chair. The reduction was also measured between flushing duration of 30 seconds, 1 minute, 2 minutes and 3 minutes of flushing. The findings would project the optimum duration required to flush DUWLs as well as to confirm the relevance of current practise of flushing for 20 seconds to 30 seconds between each patient in the 


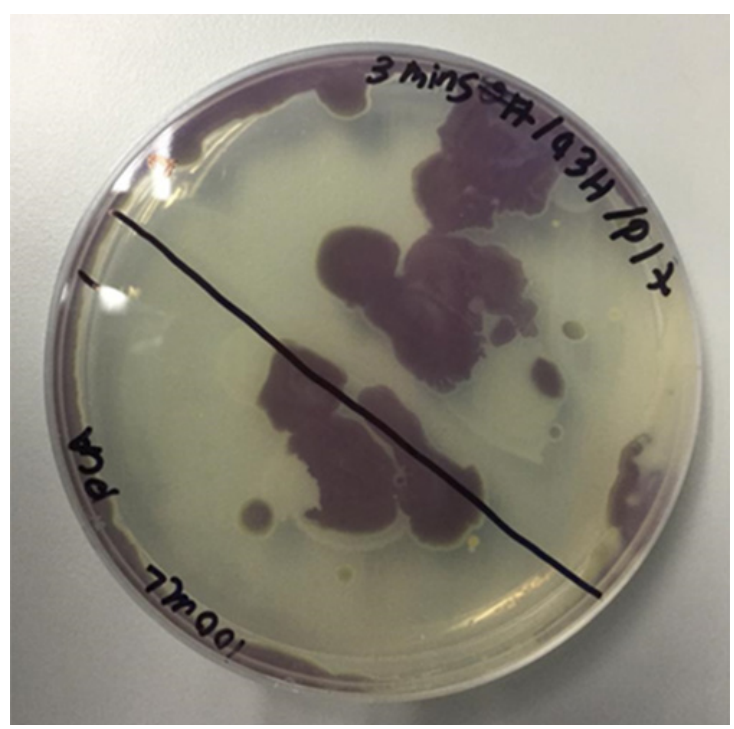

Fig. 3 Unique pattern of bacteria formed on plate count agar from polyclinic 17 water samples after spread-plate technique.

clinics as recommended by both CDC and Malaysian Dental Association (MDA).

The evaluation was performed based on the available designated water supply in USIM for better quality improvement management. The municipal water supply is periodically monitored by the Ministry of Health $(\mathrm{MOH})$. The reservoir tank on the top of the roof of the USIM building was supplied by municipal water. The main supply was then distributed through reinventing the type of water filter prior to the side water tap supply in the clinics. USIM dental clinics are currently adopting the MDC recommendation guidelines by only practicing flushing DUWLs 1 minute every morning prior to dental treatment and in between patients without the use of chemical germicides. The annual maintenance service is only carried out for the first three years after installation of the dental units. After that, the technician will only attend if there is any impending problem from the dental chairs. Nevertheless, the routine daily cleansing of suction tubing hose of the used dental chair is still conducted daily with the antibacterial solution based on the manufacturer's instructions at the end of dental clinics operating hours.
As an overall, the result shows that flushing DUWLs did reduce the level of HPC bacteria. Constant reduction of mean HPC level can be seen after 30 seconds of flushing DUWLs for all the samples collected from the baseline reading, with most significant reduction noted after 1 minute of flushing in the majority of the samples. These water samples were collected from dental units that left unoperated for 16 hours at OS and OP clinics. On the other hand, after 64 hours of not operating dental units, a longer flushing time of 3 minutes was needed to significantly reduce the mean HPC level. At OP clinic, the reduction was notably observed after 30 seconds for 64 hours of not operating the dental chair unit, meanwhile at OS clinic the reduction occurred after 3 minutes for 64 hours of not operating the dental chair unit. The possible reasons could be the OS clinic is situated further away from the source of water supply than the OP clinic. Therefore, the course of piping for water dispensing to the OS clinic is relatively longer. Besides, there is a relatively more luminal surface catered for biofilm formation accompanied by microbial attachment within the 64 hours duration. These lead to higher risk of dislodging more microorganisms from the biofilms during the flushing process.

Flushing DUWLs after 30 seconds and 2 minutes showed a fluctuation of mean HPC level for all samples. From the result, we suggest that the non-uniform level of HPC may be due to erratic sloughing of bacterial biofilm into bulk water during flushing procedure.

The highest level of HPC found on samples from polyclinic 17. This result may be due to absence of ceramic filters in these dental units. Ceramic filters were incorporated on other dental clinics in this study. Therefore, we are suggesting the consideration of placing ceramic filters in dental units is a worthwhile filter to reduce the level of HPC bacteria. This study chose pour plate technique for the cultivation of water samples from polyclinic 17 based on a pilot study performed prior to this study. During the 
pilot study, all samples were subjected to spread plate technique. However, CFUs count for samples from polyclinic 17 were undetermined after incubation due to its unique pattern of bacteria growth as shown in Fig. 3. Pour plate technique enabled the microorganisms to grow within and on the surface of the medium which made the counting of colony forming units possible but the colonies that formed were usually smaller (Dichter et al., 2017).

Table 3 shows significant difference of flushing DUWLs between 16 and 64 hours of not operating dental chairs at OP clinic where higher HPC level was found after 64 hours of not operating the dental unit. The basis of time selection was according to dental chair operating schedule. Sixteen hours were determined from weekday 5 p.m. evening onwards when the clinic was finished to the following weekday 9 a.m. morning before the clinic resumed to operate. Meanwhile, the 64 hours were determined from weekday Friday 5 p.m. onwards throughout the weekend till the following weekday Monday 9 a.m. when the clinic was resumed to operate again.

In the present study, it shows that the longer water stays stagnant inside DUWLs, there will be more bacteria and microorganism colonisation in the tubing surfaces. This finding will have an impact on the DUWL's cleaning routine for staff and students to emphasise cleaning after leaving dental units unoperated for a longer time. World Health Organization (2008) warned that raised heterotrophic plate count (HPC) levels happen particularly in stale pieces of funnelled dissemination frameworks, in household plumbing, in filtered water and in plumbed-in gadgets, for example, conditioners, carbon channels and candy machines.

However, our result was contradicted by a previous study conducted by Normaliza et al. (2013) at USIM dental clinics in which the total bacteria count from DUWLs showed less than $200 \mathrm{CFU} / \mathrm{mL}$. The reason for the discrepancy may be due to the type of agar used in their study. Only nutrient agar that cultivates less fastidious microorganisms was used in their study. In contrast, our research study utilised three different agars (R2A agar, SBA and PCA) in order to capture different populations of bacteria in the DUWLs. This might contribute to the great difference. R2A agar was used to study bacteria which normally inhabit potable water. When R2A agar was used with the spread plate procedure, it cultivates slow growing bacteria which usually suppressed by faster growing species meanwhile SBA was used for cultivation of fastidious microorganisms and lastly, PCA which also knowns as Tryptone Glucose Yeast agar or Casein-Peptone Dextrose Yeast agar was used to capture a variety of aerobic bacteria from water samples (Dichter et al., 2017).

The findings of our research were in concordance with several country-wide studies. Shahabudin et al. (2018) found that the level of microorganisms did not meet the guideline by CDC even after flushing DUWLs. Research by Cobb et al. (2002) revealed that despite continuous water flushing of four minutes, the degree of CFUs still surpassed the CDC recommendation of water safety level. Rice et al. (2006) also concluded that water treatment should never rely on flushing DUWL alone. The result of this study confirms that flushing DUWLs alone is not reliable for water quality.

Pederson et al. (2002) recommended that different methodologies other than flushing would be required to efficaciously eliminate the biofilm. Recommendations and future research should be conducted to identify the specific bacteria present in DUWLs especially Legionella spp. and freeliving protozoa. Besides, further research on specific chemical treatment for the water supply, such as the use of chemical germicides (chlorine dioxide and hydrogen peroxide) should be recommended for the removal or inactivation of biofilms in DUWLs. In addition, water tubing assessment using scanning electron 
microscopy (SEM) is also equally important to evaluate the biofilm condition inside the DUWLs tubing.

However, there is a limitation of the study as only one dental chair was chosen from the total of 35 dental chairs in polyclinic 17 . Therefore, the result of this study might not entirely represent the inference employed. Owing to it, we strongly suggest a complete sampling set of dental chairs should be applied in the future study to extrapolate the result.

\section{CONCLUSION}

Statistically from this study, there is a significant difference of flushing DUWLs between 16 and 64 hours of not operating dental chairs at both OP and OS clinics. At OP clinic, the reduction was notably observed after 1-minute of flushing for 16 hours of not operating and after 30 seconds for 64 hours of not operating the dental chair unit. While at OS clinic the reduction occurred after 1-minute of flushing for 16 hours of not operating and after 3 minutes for 64 hours of not operating the dental chair unit. This study also reveals that there is no significant difference between flushing duration of 30 seconds, 1 minute, 2 minutes and 3 minutes of flushing with baseline data for the removal of heterotrophic bacteria in DUWLs. The water quality at USIM dental clinics after the flushing duration of 30 seconds, 1 minute, 2 minutes and 3 minutes failed to meet the CDC recommendation that water used in dental treatment should contain aerobic HPC of less than $500 \mathrm{CFU} / \mathrm{mL}$. In our study, the method of flushing of DUWLs has been proven as an unreliable tool to improve water quality and therefore, it should be applied as an adjunct with other water treatment methods to improve the water quality in dental units. Regular maintenance of DUWLs should be conducted for dental units that are left unoperated for a period of time at all dental clinics (including USIM dental clinic) to safeguard dental personnel and patients.

\section{ACKNOWLEDGEMENTS}

We would like to express our heartfelt gratitude to USIM for funding this research. We would also like to thank Dr Aspalilah Alias for her contribution in statistical analysis and the laboratory technologists Mrs. Hana, Mr. Kamarulzaman and Miss Asma from Faculty of Dentistry, USIM whom have helped us conducting this research project directly or indirectly.

\section{REFERENCES}

Al-Hiyasat AS, Ma'ayeh SY, Hindiyeh MY, Khader YS (2007). The presence of Pseudomonas aeruginosa in the dental unit waterline systems of teaching clinics. Int $\mathcal{F}$ Dent Hyg, 5(1): 36-44. https://doi.org/10 $.1111 / \mathrm{j} .1601-5037.2007 .00221 . \mathrm{x}$

American Dental Association (ADA) (1999). Dental unit waterlines: Approaching the year 2000. ADA Council on Scientific Affairs. F Am Dent Assoc, 130(11): 16531664.

Cobb CM, Martel CR, McKnight SA 3rd, Pasley-Mowry C, Ferguson BL, Williams K (2002). How does time-dependent dental unit waterline flushing affect planktonic bacteria levels? f Dent Educ, 66(4): 549 555. https://doi.org/10.1002/j.0022-0337 .2002.66.4.tb03534.x

Dichter G, LeChevallier MW, Best J, Duderstadt E, Hill D, Phillipis K (2017). Heterotrophic plate count. In: Baird RB, Eaton AD, Rice EW (eds.), Standard Methods for the Examination of Water and Wastewater, 23rd edn. Washington: American Public Health Association, American Water Works Association, and Water Environment Federation, pp. 9.539.59 . 
Hernández-Jiménez E, Del Campo R, Toledano V, Vallejo-Cremades MT, Muñoz A, Largo C et al. (2013). Biofilm vs. planktonic bacterial mode of growth: Which do human macrophages prefer? Biochem Biophys Res Commun, 441(4): 947-952. https://doi.org/ 10.1016/j.bbrc.2013.11.012

Kohn WG, Collins AS, Cleveland JL, Harte JA, Eklund KJ, Malvitz DM; CDC (2003). Guidelines for infection control in dental health-care settings. MMWR Recomm Rep, 52(RR17): 1-61.

Ma MS, Zalini Y, Ahmad Razi MY, Zukri A, Haryanti T (2012). The microbiological quality of water from dental unit waterlines in Malaysian Armed Forces dental centres. Arch Orofac Sci, 7(1): 14-20.

Malaysian Dental Council, Oral Health Division, Ministry of Health (2007). Guidelines on Infection Control in Dental Practice. Putrajaya: Malaysian Dental Council, Oral Health Division, Ministry of Health.

Mavridou A, Kamma J, Mandilara G, Delaportas P, Komioti F (2006). Microbial risk assessment of dental unit water systems in general dental practice in Greece. Water Sci Technol, 54(3): 269-273. https://doi.org/10 $.2166 /$ wst. 2006.479

Mills SE (2000). The dental unit waterline controversy: Defusing the myths, defining the solutions. F Am Dent Assoc, 131(10): 1427-1441. https://doi.org/10.14219/jada. archive.2000.0054

Normaliza AM, Rohazila MH, Wan Othman WMN (2013). Microbial contamination level of water supply system at the Faculty of Dentistry, USIM, Malaysia. Sains Malaysiana, 42(1): 53-58.

Panagakos FS, Lassiter T, Kumar E (2001). Dental unit waterlines: Review and product evaluation. F N F Dent Assoc, 72(2): 20-25.
Pankhurst CL (2003). Risk assessment of dental unit waterline contamination. Prim Dent Care, 10(1): 5-10. https://doi.org/10.1308/ 135576103322504030

Payment P, Coffin E, Paquette G (1994). Blood agar to detect virulence factors in tap water heterotrophic bacteria. Appl Environ Microbiol, 60(4): 1179-1183. https://doi .org/10.1128/AEM.60.4.1179-1183.1994

Pederson ED, Stone ME, Ragain JC Jr, Simecek JW (2002). Waterline biofilm and the dental treatment facility: A review. Gen Dent, 50(2): 190-195.

Peter SL (2008). Quantitation of microorganisms. In: Goldman E, Green LH (eds.), Practical Handbook of Microbiology, 2nd edn. Boca Raton: CRC Press, pp. 11-19. https://doi.org/10.1201/ 9781420009330

Pouralibaba F, Balaei E, Kashefimehr A (2011). Evaluation of gram negative bacterial contamination in dental unit water supplies in a university clinic in Tabriz, Iran. f Dent Res Clin Dent Prospects, 5(3): 94-97. https://doi.org/10.5681/joddd.2011.021

Rice EW, Rich WK, Johnson CH, Lye DJ (2006). The role of flushing dental water lines for the removal of microbial contaminants. Public Health Rep, 121(3): 270-274. https:// doi.org/10.1177/003335490612100308

Shahabudin S, Hami R, Lim LS, Salleh A (2018). The effect of dental unit waterline flushing on the quality of water in dental teaching center in Malaysia. $\mathcal{F}$ Biomed Clin Sci, 3(1): 72-74.

Singh R, Stine OC, Smith DL, Spitznagel JK Jr, Labib ME, Williams HN (2003). Microbial diversity of biofilms in dental unit waterlines. Appl Environ Microbiol, 69(6): 3412-3420. https://doi.org/10.1128/ aem.69.6.3412-3420.2003 
Szymańska J, Dutkiewicz J (2008). Concentration and species composition of aerobic and facultatively anaerobic bacteria released to the air of a dental operation area before and after disinfection of dental unit waterlines. Ann Agric Environ Med, 15(2): 301-307.

Walker JT, Bradshaw DJ, Bennett AM, Fulford MR, Martin MV, Marsh PD (2000). Microbial biofilm formation and contamination of dental-unit water systems in general dental practice. Appl Environ Microbiol, 66(8): 3363-3367. https://doi .org/10.1128/aem.66.8.3363-3367.2000
World Health Organization (2008). Guidelines for Drinking-water Quality. Incorporating the First and Second Addenda, Vol. 1: Recommendations, 3rd edn. Geneva: World Health Organization. 